TECHNICAL NOTES AND MANUALS

\title{
Revenue Administration:
}

Administering Revenues from

Natural Resources-A Short Primer

Prepared by Andrea Lemgruber and Scott Shelton

Fiscal Affairs Department

I NTER NATIONAL MONETARY FUND 


\section{INTERNATIONAL MONETARY FUND}

Fiscal Affairs Department

Revenue Administration:

Administering Revenues from Natural Resources-A Short Primer

Prepared by Andrea Lemgruber and Scott Shelton

Authorized for distribution by Sanjeev Gupta

April 2014

DISCLAIMER: This Technical Guidance Note should not be reported as representing the views of the IMF. The views expressed in this Note are those of the authors and do not necessarily represent those of the IMF or IMF policy.

\begin{tabular}{|l|l|}
\hline JEL Classification Numbers: & $\mathrm{H} 20, \mathrm{H} 23, \mathrm{H} 25, \mathrm{H} 27$ \\
\hline Keywords: & $\begin{array}{l}\text { Tax Administration, Revenue Administration, Natural Resource } \\
\text { Taxation, Extractive Industries }\end{array}$ \\
\hline Authors' E-Mail Addresses: & alemgruber@imf.org and sshelton@imf.org \\
\hline
\end{tabular}




\section{TECHNICAL NOTES AND MANUALS}

\section{Revenue Administration: Administering Revenues from Natural Resources- A Short Primer ${ }^{1}$}

This technical note addresses the following questions:

- What are the context and main features of natural resource (NR) tax administration?

- What are the special challenges for NR tax administration?

- How should a tax administration organize itself to manage NR taxation?

- What key procedures should be in place to ensure effective NR tax administration?

- What specific capacity concerns should be addressed?

- How can transparency be improved in NR tax administration?

Many developing countries have significant natural resource endowments, presenting a remarkable opportunity to boost long-term growth. However, this opportunity comes with enormous challenges. To maximize social and economic benefits, strong governance and institutional capacity are essential along the whole value chain that turns NR endowments into sustainable development and poverty reduction. Administering NR fiscal regimes is one essential piece of the NR value chain. An effective and transparent tax administration is crucial for properly managing NR revenues within a legally-approved tax system, so the country may benefit economically and socially from its natural resources. This note describes the challenges that developing countries face in NR tax administration and presents good practices to help build countries' long-term institutional capacity.

\section{What are the Context and Main Features of Natural Resource (NR) Tax Administration?}

NR revenues, which are substantial in many countries, have major macro-fiscal relevance. ${ }^{2}$ In 2011, these revenues accounted for over 50 percent of government revenues in petroleum-

\footnotetext{
${ }^{1}$ Prepared by Andrea Lemgruber and Scott Shelton, with inputs from Jack Calder. Based on the "Natural Resource Revenue Administration Handbook" (forthcoming). Dara Veung provided excellent research assistance.

${ }^{2}$ NR revenues are receipts collected by governments from the NR sector through diverse tax and non-tax fiscal instruments. For example, NR revenues include "common" taxes, such as the corporate income tax and value added tax; special taxes on the sector, such as the resource rent tax; and other quasi-tax or non-tax instruments, such as royalties, profits, and bonuses. There is a wide variation across countries regarding which types of NR revenues
} 


\section{Box 1. Main Features of the NR Sector and their Impact on Revenue Administration}

Non-renewability: Governments normally assert ownership of finite non-renewable NR and require payment for their extraction. Special NR taxes - for example, royalties and RTTS depart from the regular tax system and are sometimes administered by non-tax departments, fragmenting the administration of the NR fiscal regime and posing challenges for interagency coordination.

Varied scale and profitability: The wide range of scale of operations can result in taxpayer segments with different tax regimes that pose different administrative challenges; for example, different compliance risks arising from diverse mining operators, such as artisanal miners and multinational companies.

Exceptional rent-generating potential: To capture the resource rent, governments normally charge higher-than-normal taxes on NR. This practice creates exceptional transfer pricing (TP) risks, which governments may seek to mitigate by adopting benchmark-based pricing. Governments also need special ring-fencing tax rules so that higher taxes on NR extraction are not reduced by extraneous costs; however, countries generally do not want those higher taxes to apply to NR processing.

High uncertainty and risk: NR companies seek high reward (rent) commensurate with high risk. Governments seek to capture a share of the rent, but profit uncertainty may encourage reliance on ad valorem royalties that are not responsive to profitability. In practice, complexities are often introduced to make them more responsive, complicating administration. Also, exceptional risk may require special tax rules for finance costs and hedging. Finally, risks may change over time, which is a factor encouraging negotiation of special tax deals rather than the uniform application of tax law. As a result, the proliferation of special deals can make the law opaque and create a proliferation of NR fiscal regimes, significantly complicating administration.

rich countries, and approximately 20 percent in mining-producing countries and countries with both mining and petroleum extraction industries (Figure 1). The importance of - and dependence on-the NR sector is higher in developing countries. Indeed, the concentration of revenues in the oil sector can reach levels of 80 percent or more in countries like Angola, the Republic of Congo, Equatorial Guinea, and Nigeria. Moreover, future trends look optimistic in terms of reserves, with significant NR potential estimated for certain regions, in particular subSaharan Africa (World Bank, 2011). This is a remarkable opportunity to foster development and reduce poverty, but it comes with significant challenges for many low-income countries.

Countries have adopted special fiscal regimes for the NR sector. These regimes are designed to introduce rules and regulations to address the particular characteristics of the

fall under the legal competency of tax administrations. This issue is addressed in more detail in the section "How should a tax administration organize itself to manage NR taxation?" Overall, this note intends to provide good practices in dealing with whichever NR revenue is within a tax administration's mandate. 


\section{Box 1. continued}

Substantial capital investment: Some governments provide tax incentives to attract private investment, conflicting with the desire for early revenue. This can result in complex tax rules for large-scale capital expenditure, presenting administrative challenges. At times, incentives take the form of tax holidays, which are often problematic from both policy and administrative viewpoints. For example, foreign tax credits for NR taxes may be important to attract foreign investors but can be lost through tax holidays.

Long development and operating periods: Delays in reaching profitability provide an incentive to impose royalties to secure early government revenue. Special loss relief rules may be needed, as well as special returns and audit procedures for pre-profit periods. Specific rules are also needed for abandonment reserves or funds. Companies face major risks from changes to the NR tax regime once they have sunk costs. It is common for governments to provide assurances of stability and negotiate special tax arrangements governed by contract law, with rights to international arbitration. These types of arrangements pose considerable administrative challenges.

Geographic concentration of NR: This may encourage specially negotiated tax regimes for different geographical areas, complicating the legal framework and administration of revenue collection. It may also encourage fiscal decentralization, requiring effective intergovernmental coordination.

High levels of exports and imports: These contribute to TP risks and require effective customs control, a robust value-added tax (VAT) refund system, and a sound exchange of information between the tax and the customs administrations. In addition, the high level of foreign payments makes withholding taxes (WHT) important, and special rules may apply.

sector, such as non-renewability, exceptional rent-generating potential, extensive involvement of multinational companies and state-owned enterprises, exhaustibility, and high uncertainty and risks, combined with a varied scale of profitability for individual projects. These features pose specific challenges to tax administrations (Box 1). Furthermore, from the macro-fiscal perspective, a key characteristic of the NR sector is price volatility, making government revenues significantly pro-cyclical (Figures 2 and 3). Counteracting the pro-cyclicality and planning for its exhaustibility is relevant for these economiesmeaning that non-oil taxes and their administration should not be neglected during the NR boom years. ${ }^{3}$

\footnotetext{
${ }^{3}$ This note does not specifically address non-NR tax administration issues, but it is important to highlight that establishing a modern tax administration should be the objective of any country. A sound tax administration allows both NR and non-NR revenues to be collected more effectively and efficiently. Indeed, fundamentals and core processes are the same, and the better a general tax administration framework, the easier it will be to collect NR taxes.
} 
Figure 1. Revenues from Natural Resources, Selected Countries, 2011
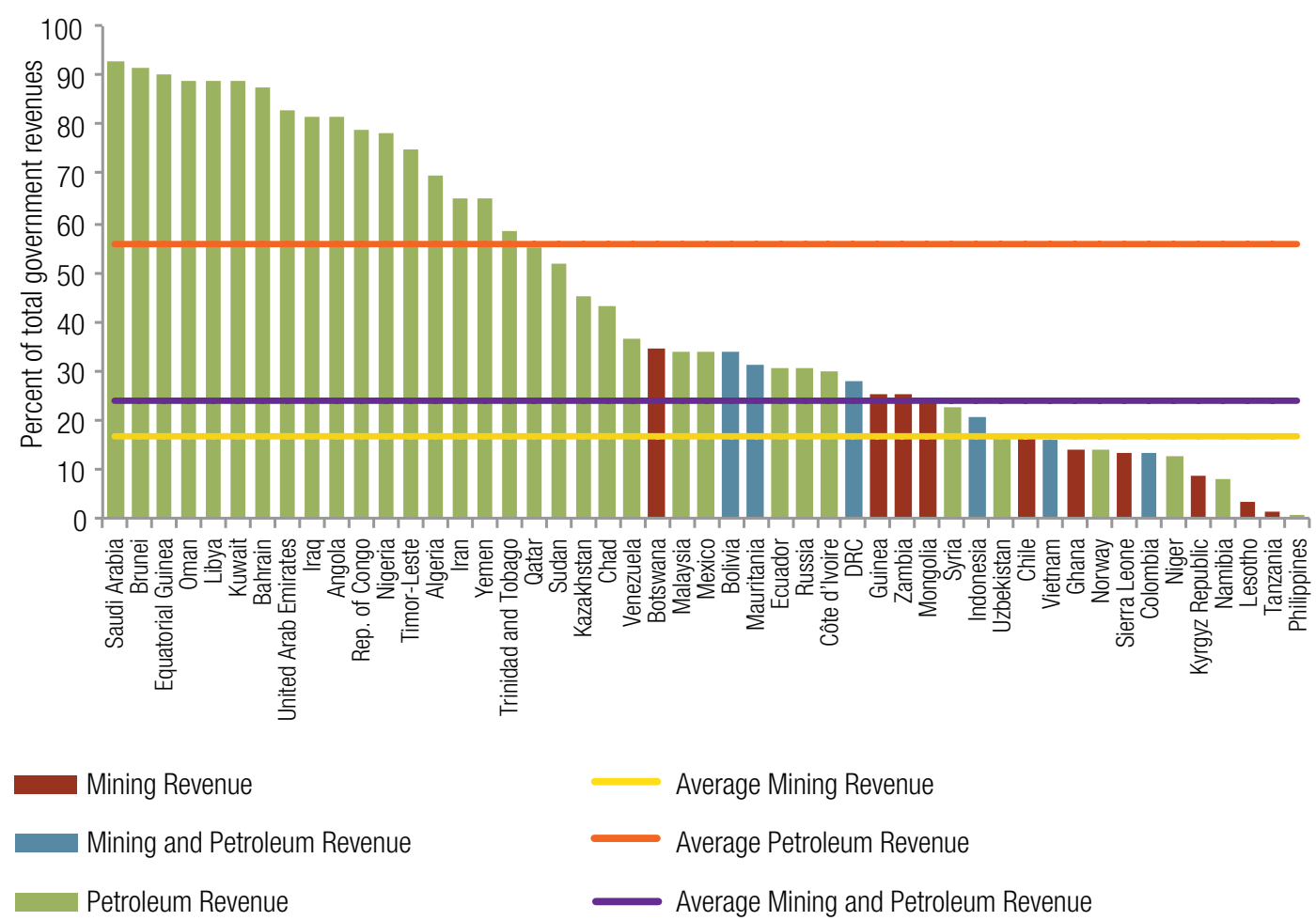

Source: IMF staff estimates

NR fiscal regimes typically involve the choice of taxing several bases through a combination of instruments to address the above-mentioned specificities, including the following: ${ }^{4}$

- Transactions, such as license fees and signature/production bonuses.

- Volume or value of production, such as royalties.

- Consumption, such as the VAT and export duties.

- Profits or gains, such as the corporate income taxes (CIT) and capital gains.

- Excess profits, such as resource rent taxes (RRTs) and variable income taxes intended to capture rents.

- Others, such as minor "nuisance taxes" and area rentals.

The specific nature of these regimes_in comparison to "normal" business taxation—creates complexity and poses technical challenges to tax administrations (in addition, the design of

\footnotetext{
${ }^{4}$ The broad choice of NR tax bases and rates should be regarded as primarily a policy issue rather than an administrative issue. Governments have to choose the most suitable mix of tax bases and tax rates to meet their particular economic tax policy objectives in terms of such issues as revenue, risk, competitiveness, and investment incentives. Ease of administration must be secondary to those broad economic objectives. However, the aim should be to meet these broad objectives without imposing unnecessary administrative complexity, and ease of administration should be an important consideration in the detailed design of the taxes chosen.
} 
Figure 2. Revenues from Hydocarbons ${ }^{4}$

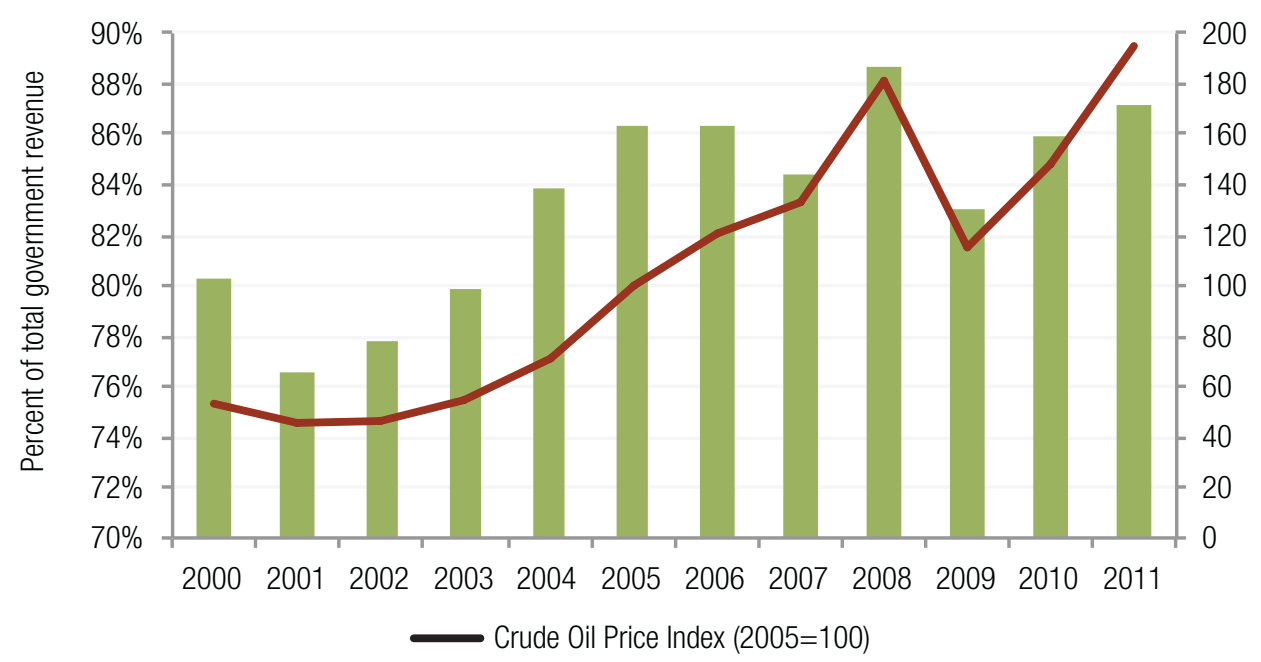

Source: IMF staff estimates.

Note: "Average 10" refers to, in order of decreasing resource revenue as a share of total revenue over 2000-11), Iraq, Brunei, Equatorial, Guinea, Saudi Arabia, Libya, Oman, Kuwait, Angola, Bahrain, and Congo Republic.

\section{Figure 3. Revenues from Mining}

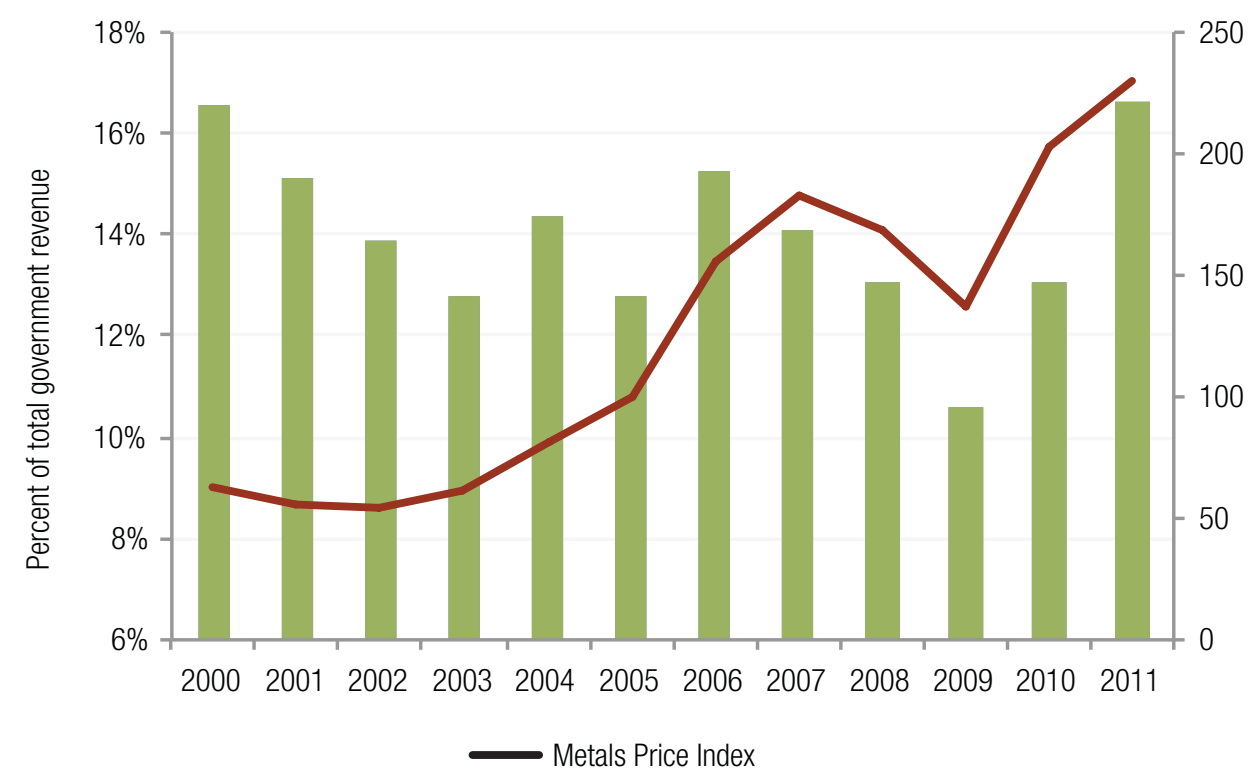

Source: IMF staff estimates.

Note: "Average 10" refers to, in order of decreasing resource revenue as a share of total revenue over 2000-11, Botswana, Guinea, Mongolia, Chile, Zambia, Ghana, Kyrgyz Republic, Sierra Leone, Lesotho, and Tanzania.

these regimes is unnecessarily intricate and overly opaque in some countries). Furthermore, the concentration of revenues in just one sector or in a few companies may also give rise to integrity and transparency issues. 


\section{What are the Special Challenges for NR Tax Administration}

NR tax administrations face a number of challenges:

- Administering departures from standard tax legislation, which requires significant specialization, including (1) special taxes, such as royalties, progressive, or rent-based taxes, and bonuses; (2) specially negotiated contract-based tax regimes; and (3) particular NR-related tax provisions, such as benchmark-based pricing, ring-fencing, cost recovery limits, deduction of abandonment reserves, and investment incentives.

- Dealing with variations in fiscal terminology and legal frameworks across different projects or from one type of NR to another, such as petroleum and mining.

- Identifying and controlling major TP risks.

- Administering taxes subject to stability clauses, which may be unclear and may pose difficulties in reforming the legal and administrative framework.

Accordingly, a key precondition for effective administration is having a sound and simple legal framework in place. Tax administrations have an important tax policy advisory role, which is usually not recognized or developed. The administrative implications of any law should thus be fully assessed before they are presented to the legislature. Sufficient time and resources should be allocated for personnel training and for undertaking preparatory work, such as changes to information technology systems and the development of new tax forms. Box 2 describes major NR-related legal issues affecting tax administrations.

\section{How Should a Tax Administration Organize Itself to Manage NR Taxation?}

\section{Organization at the Governmental Level}

NR tax administration takes place within a wider government policy and regulatory framework. This framework covers not only fiscal policy and regulation, but also NR management, industry policy and administration, and, where relevant, commercial participation. The fiscal regime for NR companies will generally be set out in the tax legislation, and the tax administration will be responsible for its implementation. Table 1 sets out the likely NR organizational framework for cases where the finance ministry is wholly responsible for determining and implementing NR fiscal policy, as the IMF typically recommends. Table 1 assumes govern-

\begin{tabular}{|l|l|l|}
\hline TABLE 1. NR ORGANIZATIONAL FRAMEWORK \\
\hline & Policy & Execution \\
\hline Fiscal & Finance Ministry & Tax and Customs Administrations \\
\hline NR Management/Operations & NR Ministry & NR Inspectorate \\
\hline Commercial & NR or Finance Ministry & Natural resource company \\
\hline
\end{tabular}

Source: NR Revenue Administration Handbook (forthcoming) 


\section{Box 2. Administrative Challenges of NR-Related Legal Issues}

The valuation of NR sales: The point and the method of valuation need to be clearly defined. The valuation of minerals tends to be more problematic than oil, and there is a wide variety of approaches. Some methods of valuation for royalty purposes do not reflect arm's length (AL) prices and are unsuitable for profit-based taxes. This may simplify royalty administration considered on its own but complicates the administration of the NR fiscal regime overall.

Transfer pricing: Profit-shifting through TP presents major risks in NR taxation. Rules for countering TP abuse by NR companies are often distinctive and vary considerably among countries. General TP rules express the AL principle but do not define how it should be put into practice. The lack of objective rules for pricing non-arm's length (NAL) transactions may leave companies with latitude to manipulate TP and may make it difficult for tax authorities to enforce TP rules. General TP rules are often backed up by specific TP rules setting out in detail how NR prices are to be calculated for NAL transactions. A number of difficulties arise in applying benchmark prices to NAL sales, especially for NR other than petroleum, including manipulation of average prices, lack of benchmarks for some minerals, and difficulty of measuring mineral quality. For most NR costs, benchmarking is not practicable, but costs not governed by specific TP rules present significant TP risks. Governments should build specific TP cost rules into their legislation and agreements; advance pricing agreements are an option to consider where this is not possible.

Finance costs: Companies may avoid taxes by claiming excessive finance costs. Thin capitalization is a special type of TP problem, and there is a range of approaches to counter it. Some countries take simpler approaches than others to limiting chargeable interest rates. Countries often use ministerial or departmental discretion to limit deductible finance costs, but this approach lacks transparency. Disguised interest presents a further risk, so restrictions on deductibility need to apply to all finance charges, not only to those explicitly described as interest.

Hedging: Since NR prices are volatile, taxpayers may legitimately hedge them. However, where countries recognize hedging gains and losses in taxing NR profits, the rules can be complex and open to avoidance. Tax authorities may lack the capacity to handle these issues, despite the help of anti-avoidance provisions.

Ring-fencing: Ring-fencing means a limitation on the consolidation of income and deductions for tax purposes - so that only directly attributable costs are deductible-across different activities or projects, undertaken by the same taxpayer. Some countries ring-fence mining and oil activities, others ring-fence individual contract areas or projects (see Sunley and Baunsgaard, 2001). Ring-fencing adds potential administrative complexity and risk, and workable cost allocation rules are needed.

Rules for NR capital expenditures: There should be simple rules for categorization of tax depreciable costs. Investment allowances and credits are a possible target for tax planning and abuse, particularly where the tax rates are high. The rules for calculating depreciation can present major administrative challenges if poorly designed. There can be significant back-loaded costs for mine or well closure and environmental restoration; the need to set aside profits for this purpose should be recognized for tax purposes.

(continued) 


\section{Box 2. continued}

Social infrastructure costs: Examples of such required investments in local communities include those for health care, for the building of clinics; for education, for the building of schools and vocational training centers; and for infrastructure, for the building of roads and the providing of potable water. The law on the deductibility of these costs often requires clarification.

Transfers of NR license interests: Considerable variation exists in how these are taxed. In some countries the rules, and the interaction with depreciation rules, are complex. Companies may seek to avoid substantial tax through indirect transfers or sales for non-cash consideration.

Exemption of imports for NR operations from VAT and customs duties: Rules may be unclear or open to abuse and require consistent coordination between tax and customs administrations.

ment equity participation, generally a feature in developing countries. In this framework, the finance ministry will decide the level of state participation and oversee the NRC's tax, financial management, and accounting, while the NR ministry will determine its NR exploitation policy and oversee its operations.

In practice, there are major variations in the way countries organize NR tax administration across different agencies, including the following:

- Administration of all NR revenues by the tax administration: less common for petroleum than mining; more common in developed countries apart from those with significant fiscal decentralization. ${ }^{5}$

- Fragmentation of NR tax administration among different agencies: common in developing countries, particularly for petroleum.

- Administration of all NR revenues by the NR department or NRC: rare, but may apply in petroleum production sharing regimes.

An integrated and functionally-based tax administration is an essential element of any reform program. ${ }^{6}$ Modern tax administrations are legally constituted bodies responsible for collecting all national taxes, based on the following principles:

- Integration of direct and indirect taxes.

\footnotetext{
${ }^{5}$ In many countries, regional and local governments play a major role in the regulation and taxation of industry, which may include the NR industry.

${ }^{6}$ This view is well summed up in Kidd (2010), p. 2: "An effective organization is the basic platform from which all other procedural reforms are launched and maintained. Without the right organization structure in place, revenue administrations cannot operate effectively and their revenue efforts will be sub-optimal. Where functionbased organizations have not been implemented, the extensive procedural and operational reforms needed to support modernization would likely be ineffective."
} 
- Organization along core business functions, for example, taxpayer services, audit, appeals, and enforcement collection.

- Taxpayer segmentation, typically along small, medium, and large taxpayer segments.

- Strong headquarters office that focuses on managing operational field operations.

This integrated, functionally-based administration is equally appropriate for administering NR revenue. Clearly, there are no special features of NR taxation that make these above requirements irrelevant—on the contrary, many of them are particularly especially vital for NR taxation.

Despite the superior qualities of an integrated, functionally-based model, many countries opt for a fragmented model, for example, one in which the Ministry of Natural Resources administers fiscal arrangements such as royalties and production sharing agreements. Typical reasons include political considerations_-given the importance of NR revenues-and concerns regarding the technical ability and integrity of the tax administration, especially in lowincome countries. The authorities tend to try to overcome the disadvantages of a fragmented administration by improving cooperation, but they have not been successful. Governments rarely have the level of administrative sophistication required to manage the increased demands of cooperation required by fragmented administration. Fragmentation ends up being a great disadvantage, causing weak administration and loss of taxpayer control, increasing red tape, and imposing extra compliance burden on businesses.

When choosing a particular model, a country should follow some basic recommendations regarding the organizational framework for NR revenue administration. Clearly, conflict of interest and transparency concerns should rule out the integration of NR tax administration within a commercially active NRC. Arguments can be made both for and against the integration within the NR department versus the tax administration (Table 2); on balance, integration within the tax administration is internationally accepted as the better option. However, in this recommended model, the tax administration should obtain input and assistance from the NR department, which can provide useful specialist knowledge.

Cooperation and exchange of information among departments dealing with NR administration need to be improved in most NR-rich countries. Even where NR tax administration is integrated in a single department, the exchange of information with other departments remains important; the lack of cooperation, in particular between the tax authority and the NR ministry, can be problematic. Where NR tax administration is fragmented, poor cooperation is an even more serious issue. An essential step is to clarify and document each agency's responsibilities, including by establishing memoranda of understanding and exchange of information agreements that clearly define competencies, deadlines, and the specifics of the information to be shared (for example, by whom, to whom, what type of information, and by when?). Once the responsibilities are clearly established, the effective exchange of information procedures should be put in place, ideally automatically and electronically. 
TABLE 2. ADVANTAGES AND DISADVANTAGES OF INTEGRATION WITHIN THE NR DEPARTMENT VERSUS TAX ADMINISTRATION

\begin{tabular}{|c|c|}
\hline Advantages & Disadvantages \\
\hline $\begin{array}{l}\text { - The approach to NR management and NR fiscal policy is } \\
\text { more integrated. } \\
\text { - Companies have a one-stop shop for both fiscal and } \\
\text { industry regulation. } \\
\text { - NR expertise can be concentrated in a single agency. } \\
\text { - That agency's specialist expertise and its responsibility } \\
\text { for overseeing industry operations may be advantageous } \\
\text { for the effective audit of company tax returns. }\end{array}$ & $\begin{array}{l}\text { - Specialist legal, audit, accounting, and financial reporting } \\
\text { skills are more important for NR revenue administration } \\
\text { than industry technological skills. These skills are most } \\
\text { developed for general tax administration, not NR depart- } \\
\text { ments. } \\
\text { - Allocation of tax administration responsibilities to NR } \\
\text { departments increases capacity demands on them and } \\
\text { weakens their focus on their primary job. } \\
\text { - Regulation of NR operations requires real-time interven- } \\
\text { tion. Regulation should not be mixed with tax administra- } \\
\text { tion, but keeping these functions clearly separated can } \\
\text { be difficult. } \\
\text { - Tax regulation is arguably inconsistent with the NR de- } \\
\text { partment's role of promoting and supporting the industry. } \\
\text { - NR companies will be subject to taxes that are not NR- } \\
\text { specific (for example, WHT, VAT, pay as you earn, and CIT } \\
\text { on non-NR income }{ }^{1} \text { ), which can be significant. The NR } \\
\text { department is not qualified to administer these. }\end{array}$ \\
\hline
\end{tabular}

Source: NR Revenue Administration Handbook (forthcoming).

${ }^{1}$ Capital gains on license transfers are normally taxed as non-NR income.

\section{Organization at the Revenue Administration Level}

It is important to develop specialist expertise in the NR industry and the special fiscal rules that normally apply to it. Such specialization can be developed within a predominantly function-based organization, taking advantage of the international practice to segment taxpayers according to their characteristics and risks. To that effect, modern tax administrations have an elite large taxpayer office (LTO), generally responsible for closely managing the taxpayers that account, collectively, for about 60 percent or more of total revenue. NR companies, given their size and particularities, fit into the large taxpayers segment and are administered more effectively within the LTO setting. A separate NR unit may exist within the LTO, or specialist NR jobs can be established within the LTO's functional divisions for such issues as audit, taxpayer service, risk assessment, and legal and policy matters. The choice depends on the size of the LTO/NR unit and how to better organize the work within the office. Also, NR specialist jobs may exist at the Headquarters level (dealing with policy, strategy, planning, and monitoring), to allow for a coordinated and integrated risk-based approach in administering the sector.

Nevertheless, similar to the fragmentation that occurs at the governmental level, many tax administrations choose to create a separate NR unit outside of the LTO. Reasons for this choice are similar to the ones at the governmental level; it may involve the intention of controlling NR taxpayers through a separate unit that is closely related to the top management for political reasons, or it may be a way to "start from scratch" the NR administration in an 
isolated setting, without having to deal with existing issues relating to integrity and low capacity at the tax administration level. In any case, creating an isolated unit is not a permanent solution as it will lead to duplication, increased administrative costs and possible inconsistent treatment within the whole of the country's tax base.

Also, these specialized NR units can create a "two-speed tax administration" running in parallel which, if best practices are not shared, jeopardize a country's long-term institutional capacity building. Effective communication and coordination within the gamut of the revenue administration's overall compliance strategy between the NR unit and the rest of the tax administration is essential. NR taxation should be seen as a part of the overall tax administration, to be achieved through a fully-functional, integrated, transparent and effective organization with a holistic and risk based approach for each industry segment.

Finally, an important piece of the NR revenue administration framework is related to the customs administration. Depending on the country, the customs administration may be integrated with domestic taxes in a single revenue administration or established as a standalone department under the Ministry of Finance. Either way, customs has an important role in NR revenue administration, because the sector operates with high import level (for example, capital goods) and export level (for example, oil and minerals). Beyond the need for an effective customs control in itself, these sizable trade transactions have a relevant impact on domestic taxes administration, such as VAT refunds (for example, those related to zero rating exports) and the CIT cross-check mechanism (for example, when exports are the main source of reported income for CIT purposes and valuation of imports provide reference points for expenditures for CIT purposes). A robust customs control, associated with trade facilitation and based on a systematic exchange of information with the domestic tax department, is very important for the overall success of the NR revenue administration and merits additional attention.

\section{What Key Procedures Should Be in Place to Ensure Effective NR Tax Administration? ${ }^{7}$}

\section{Setting up an Overall Compliance Strategy for the NR Sector}

A key element for an effective NR tax administration is developing and implementing a coherent compliance strategy for the NR sector. The strategy should include all main aspects related to administering the sector, identifying the units involved, as well as their responsibilities and goals. The amounts of revenues at stake are usually significant and the tax administration should design a strategy aimed at properly managing the associated risks for tax compli-

\footnotetext{
${ }^{7}$ This document deals with the specifics necessary to provide for the efficient and effective administration of NR revenues. However, there will be significant commonalities in the relevant processes and structures necessary for the effective revenue administration of all economic sectors. The development of specific processes for the NR sector should recognize the need for consistent treatment of all sectors and be used as a catalyst for positive change across the whole tax administration.
} 
ance, as highlighted in Boxes 1 and 2. The strategy could focus on maximizing compliance and articulating the relevant sub-strategies to achieve this goal. These may include fostering effective cooperation with other government agencies to exchange information; adopting a risk-management framework to effectively control and service NR taxpayers; and achieving a faster and impartial dispute resolution mechanism. These strategies should be operationalized by assigning responsibilities to specific units who develop activities and processes under an implementation plan within defined timeframes.

For those administrations that are starting the process (for example, after the discovery of NR), an issue that should not be underestimated is how to set up a NR tax unit from scratch. In this case, the recommendation is to build on any existent LTO. Even then, a detailed strategy and action plan for setting up the specialized NR tax unit and teams is needed. The action plan requires significant planning and management capacity, as well as time. Issues to be addressed in the action plan include the following:

- Appointing the head of the unit and team members and selecting the specialists who will work on NR, which may involve an internal and external selection.

- Defining offices and facilities.

- Designing new NR-specific IT systems, such as prices databases.

- Signing memoranda of understanding with partner agencies prior to the initiation of operations.

- Investing in training and factoring in any necessary requests for technical assistance.

- Communicating the new approach to NR administration to taxpayers.

\section{Establishing Coherent and Harmonized Procedures}

The design and implementation of procedures for NR tax administration should accord with

good practice in general tax administration. The main elements of good practice can be summarized as follows:

- Harmonized and streamlined legislation in a tax procedure code (TPC) covering registration, filing of returns, payment, arrears enforcement, interest, penalties, audit, and dispute resolution.

- Separation of functions where necessary to safeguard integrity.

- Efficient and effective routine processing of registration, filing and payment, with filing based on self-assessment.

- Taxpayer service, audit and enforcement planned on the basis of risk management and taxpayer segmentation.

- Comprehensive and targeted taxpayer service programs to foster voluntary compliance.

- Active enforcement of registration, filing, payment, and arrears recovery.

- Effective, fair and accessible dispute resolution.

- Timely and accurate revenue reporting at the individual and aggregate levels. 
Procedures should be designed and implemented with a view to allowing the tax authority to carry out its functions in a standardized and transparent way, and to report and account accurately for government NR revenues. The fragmentation of NR administrative responsibilities is often one of the main reasons why procedures are complex, inconsistent, and ineffective. In order to establish standardized and streamlined procedures across different taxes, modern tax administrations utilize a tax procedure code (TPC). Where a general TPC exists, it should include NR tax procedures so as to create greater consistency between different NR taxes, and between them and general taxes. This inclusion of NR issues in the general TPC is normally possible with only a limited number of special procedural rules for NR taxes. However, there are circumstances in which different departments administer NR taxes, and a TPC may have to apply only to those administered by the tax administration. In such cases, where the NR fiscal regime is part of a contractual agreement or another act not administered by the tax administration, attempts should be made to harmonize the procedural rules applied by different departments as much as possible.

As in the general tax administration case, procedures related to NR taxpayers can be separated out as those that apply to "routine functions" and "non-routine functions." Routine functions (registration, returns and payments processing, and assessment) are about the mechanics of gathering taxes from taxpayers. Non-routine—or technical—functions (taxpayer service; enforcement against taxpayers who fail to register, file, or pay; physical audit; benchmark pricing; audit of returns; dispute resolution; and policy advice) are about ensuring tax is quantified correctly and dealing with noncompliant taxpayers, if necessary. The main compliance risk faced by administrations is generally that the tax declared does not accord with the law or its underlying policy intention (sometimes using aggressive tax planning). This is a complex issue dealt with by non-routine functions. In addition to implementing procedures in line with good practices for general taxation, there is often considerable scope for making NR routine and non-routine procedures simpler, more coherent, and more efficient.

This classification between routine and non-routine functions is important to establish a more effective and targeted taxpayer control. Routine functions do not require specialized industry knowledge and should be fully integrated into the generic functional organization. However, non-routine functions require specific NR-industry expertise that is best handled by skilled specialized teams. As mentioned previously, these teams should be located within the domestic tax administration (ideally in the LTO and key Headquarters' functions, where appropriate) to minimize fragmentation and ensure consistency of policies and procedures across economic sectors. Both types of functions are analyzed in the next section.

\section{Routine Functions}

For large NR companies, which generally represent the bulk of the revenues at stake, noncompliance with routine requirements is usually not a problem. These taxpayers typically are well-informed and comply with their routine tax obligations (for example, the obligation to register, submit tax returns, and pay on time). Of course, for this to happen, the tax adminis- 
tration needs to have the basics in place: an effective self-assessment system, backed by clear guidance and rigorous enforcement, and including automatic interest and penalties, which many low-income countries do not regularly apply.

Noncompliance with routine requirements, and omissions from returns caused by inadequate or inaccurate records, are more common with small-scale artisanal miners. The size and growth of this type of informal activity can be relevant in many countries, posing risks to the tax administration. Measures outside the remit of tax administrations may be necessary to bring artisanal mining activity into the formal economy. Tax authorities may also need to take special measures to manage the mining shadow economy. With this sector, the strategy needs to be different and allow for additional investments in educating miners about basic tax obligations, including registration, to bring them to the tax net.

Implementing the basics of routine functions effectively is not an easy task, especially for low-income countries. Many countries do not have information technology capacity to offer electronic services for return submission and payment, even for large taxpayers. Also, many tax administrations struggle to properly control stop filers, late filers, and late payers. Therefore, considerable scope often exists for making NR routine procedures simpler, more coherent, and more efficient. Key issues include the following:

\section{Return Submission}

- Tax authorities normally require separate returns for different taxes, but consolidated returns, where appropriate, may make administration easier and more efficient. Careful attention should be given to designing a return that is simple, has clear language and asks for the necessary information to assess and review the veracity of the liability. Simplification does not necessarily mean shorter returns (NR taxpayers and their advisors have the information available to prepare returns that require relevant data in a clear and coherent format).

- Moreover, NR tax returns should be designed to support audit risk assessment. Information on specific risk issues such as international holdings and transactions may be required.

- Ideally, NR taxpayers should submit returns only in electronic format.

- Some NR taxes are charged on an annual basis and some on the basis of a shorter period; a consistent annual basis, where appropriate, would simplify administration.

\section{Payment}

- Ideally, cash payments should not be accepted in tax branches-especially in countries that have a reliable financial sector. In particular, large taxpayers, NR included, should pay directly in banks or electronically.

- Tax authorities often have complex procedures for allocating payments among different revenues, creating unnecessary record keeping and complicating tax accounting. Integrated administration using consistent procedures, common payment rules for different 
revenues, and a payment coding system can make payment control much more efficient. Controlling payment effectively also reduces the problems associated with refunds.

- There is considerable variation in the timing and frequency of in-year installments of annual NR taxes, as well as variation in the basis for calculating them. Installments based on the provisional results of a period are more difficult to administer than the simpler estimate-based approaches, but, if used consistently, are more straightforward than some of the complex estimate-based approaches commonly found.

- Payment of petroleum revenues in kind presents special challenges for administration. It entails costs and risks, since storage and marketing require special competencies. Although it is worthwhile to question its benefits, many countries will want to persevere in this practice.

- There are varied approaches to foreign currency accounting and tax payment, but consistency is important for simplifying procedures. To simplify administration and accounting for the purposes of the Extractive Industries Transparency Initiative (EITI), 8 it is best to require payment of all NR taxes in the same currency.

\section{Penalties}

- Penalties for the failure to file on time need to be charged promptly and automatically, and they should be followed up by the prompt issuance of administrative assessments. Interest should be automatically charged on all late payments, without exception.

\section{Refunds}

- Large VAT refunds are common for NR companies-an export-oriented business-because exports tend to be zero-rated. Administrations need to put in place adequate procedures, including risk-based audit procedures, to deter abuse. However, administrations need to honor refund payment-delays in refunding imply huge negative effects on the taxpayers' cash liquidity. ${ }^{9}$ Moreover, an effective public financial management should be in place, including a modern cash management system, to ensure there are sufficient funds in the Single Treasury Account to pay tax refunds in a timely manner.

\section{Non-Routine Functions}

Risks involving non-routine functions are more severe and difficult to detect; these include those involving complex transactions, such as TP, hedging, and thin capitalization, result-

\footnotetext{
${ }^{8}$ EITI is a global coalition of governments, companies, and civil society entities to improve the openness and accountable management of NR revenues. The section "How Can Transparency in NR Revenue Administration Be Enhanced?" provides more detail on this initiative.

${ }^{9}$ Not paying refunds in a timely manner is a systematic problem in many NR rich-countries in sub-Saharan Africa, up to a point where more than 2 percent of GDP in outstanding arrears is accumulated. Recent IMF data (RA-FIT database) show that low-income countries refund, on average, only 7 percent of gross VAT, while in many advanced economies, this indicator can reach 40-45 percent (see also Harrison and Krelove, 2005). Tax administrations should realize that operating in a basis of gross VAT, rather than net VAT, despite inflating revenues in the short-run, is detrimental to the business environment and to the long-term tax compliance. The VAT should be refunded properly and in a timely manner, based on a risk analysis.
} 
ing in under-declaration of income or over-declaration of costs. Tax authorities have finite resources and must plan their use wisely to achieve the optimum compliance outcome. This capacity requires a systematic process to identify, analyze, prioritize, and treat the major compliance risks, with coordinated input from staff responsible for different functions. The identification of risk requires the analysis of data from both internal sources (for example, returns data, compliance levels, audit results, and taxpayer enquiries) and external sources (for example, other government departments involved in NR administration, company websites and published accounts, media reports, and subscriptions to commercial sources of price data). Risks should be analyzed at the taxpayer level and at the category level. At the taxpayer level, profiling should be carried out to place taxpayers in different risk categories, reflecting both the perceived likelihood of noncompliance and the amount of revenue at risk. Category risks relate to specific tax issues, that is, to the tax system, rather than to particular taxpayers.

The strategy for treating risks should reflect an analysis of their causes, with the goal of addressing these causes and not simply the outcomes. The components of the strategy may include the following: marketing and education campaigns; the development of explanatory products, for example, fact sheets or guides; audit components; and, in some cases, legal changes. The following procedural concerns that are specific to the NR industry should be addressed:

\section{Taxpayer Services}

- Taxpayer services encourage voluntary compliance and help to strengthen risk review. A generic taxpayer services program is usually too narrow to meet the specialized needs of NR taxpayers. Accordingly, tax authorities should develop a comprehensive taxpayer service program for the NR industry.

- Such a program should target subsets of all NR taxpayers. For small miners, for example, active intervention is needed to bring the segment to the tax net and inform taxpayers of core obligations. For large taxpayers, the concern is to deliver more personalized service through a Key Client Manager (KCM) within the LTO/NR unit to establish a working relationship with the large taxpayer. In general, advice and consultation on legal and technical issues are particularly important.

- Regular forums for consultation and discussion with key NR stakeholders are also useful.

\section{Payment Enforcement}

- Normal good practice should be followed on payment enforcement, but license termination is a special option to be considered for serious cases of non-payment of NR revenues. 


\section{Audit}

- Audit of NR tax returns is generally considered to be the most important but also the most challenging function. Tax audit and information access powers need to be adequate. Clear strategic, operational, and case audit plans should be developed for the NR sector that are based on risk assessment and reflect the special characteristics of the industry and of different taxpayer segments.

- Risk assessment and audit require the gathering and use of data from internal and external sources and can be strengthened by developing a NR database with information technology support. Risk profiling should be based upon data produced by core filters (for example, the period since the last audit, the general financial ratio analysis), NRinherent filters (for example, related party dealings, capital allowance claims, financing costs, and mining company margin analysis), and operational filters (for example, sales variances from benchmark prices and stripping ratios).

- Contract-based economic models may be useful for audit risk assessment. Non-tax audits have a role to play in risk assessment. Different types of tax audit may be appropriate for different companies, and this variation should be built into the audit strategy and planning. Special audit procedures may be appropriate for joint ventures.

- Tax administrations should audit NRCs to ensure the proper transfer of income to the general revenue fund.

- The audit of different NR revenues should be integrated within the tax administration as part of wider organizational integration; however, where the administration is fragmented, the audit activity of different agencies should be closely coordinated.

- Where production is valued on the basis of benchmark prices, clear procedures must be in place for establishing and publishing those prices. In theory, if pricing rules are clear and simple, companies can be left to apply them; in practice, it is usually more efficient if the responsible agency published the prices to be used. Governments may need advice on suitable sources of price data for benchmark-based pricing or risk assessment.

- Effective physical audit is an important element of NR administration. NR companies should be subject to clearly defined obligations to measure and record physical production, which should be monitored.

\section{Dispute Resolution}

- Equitable, accessible, and timely dispute resolution is essential for NR taxation. In many countries, judicial institutions are weak in general, and this problem is aggravated when the system is required to effectively resolve complex cases, such NR tax disputes.

- Tax administrations need to set up units to deal with objections that are separate from the functional areas that identified, calculated and processed the assessment to ensure a transparent and independent review process.

- Ideally, specialized tribunals and judges, with knowledge of the tax legislation and the NR-sector issues, are needed. General tribunals tend to be unsuitable for dealing with 
complex cases; in many instances, they end up focusing only on procedural issues, rather than substantive issues.

- The tax administration also needs to identify and train specialized lawyers to defend cases in court.

- In some cases, it may be possible to support the dispute resolution on NR taxation by providing for expert international arbitration, but a resource-rich country needs a process to build capacity in dispute resolution in NR issues on an ongoing basis.

\section{Research and Analysis}

- Contract-based economic models are an essential tool for NR tax policy development and contract negotiation, as well as for NR revenue forecasting and expenditure management. The initial responsibility for developing and maintaining them, and disseminating their results, should rest with the finance ministry. The models can also be used to explain actual outturns against forecasts and may play a useful role in risk assessment, requiring their use by revenue administrations as well.

- Tax administrations need to develop the analytical capacity to understand the sector and its performance within the business cycle, as well as to provide inputs to the formulation of tax policy and support to forecasting systems.

\section{What Specific Capacity Concerns Should be Addressed?}

As discussed, effective NR tax administration presents challenges to capacity. In particular, NR are often found in developing countries, many of which still struggle with routine clerical functions, let alone the difficult technical functions of mineral valuation and financial audit required for effective NR revenue administration. However, NR taxpayers are not the "average" taxpayer in these countries: multinational NR companies employ top lawyers, analysts, accountants, and tax specialists, some specifically tasked with reducing their tax bills. The imbalance in expertise between tax administrators and NR companies can make effective fiscal control difficult. Against this backdrop, understanding the NR industry is clearly important for taxing it effectively. The fact that the NR sector is a highly regulated business with operations that can be physically monitored provides an opportunity for a more effective tax administration than would be possible with other sectors; financial data can be crosschecked against data on physical operations.

However, governments often fail to take the basic steps needed to develop adequate capacity for administering large NR companies. Where NR operations are concentrated in a small number of companies (or, in some cases, one company) contributing a disproportionate share of government revenue, the special importance of effective administration of those companies is obvious. If, in general, the tax administration's capacity is weak, exceptional measures are needed to strengthen the capacity of the small number of staff responsible for key administra- 
tive roles relating to those companies. Those measures must ensure that these staff have better qualifications, training, pay, grading, authority, and status than staff doing less specialized work. Key issues include the following:

\section{Staffing}

- Where the great majority of NR revenues are payable by companies that the LTO handles, it is particularly important to adequately staff the LTO. The allocation of staff to large company NR revenue administration should be based on a detailed assessment of the number of staff required for effective implementation of the NR compliance strategy, balancing those working on audit (which involves, typically, the largest number of employees working on the NR sector) and those working on taxpayer services (for example, KCMs). This allocation, in turn, should reflect well-designed risk-based audit and taxpayer service strategies tailored to different taxpayer segments.

- The adequate number of staff working on NR depends on the country. The tax administration should plan according to (1) the size and complexity of the NR sector (for example, only oil, or a combination of oil and mineral? What is the size of production and revenues at stake?), (2) the number of taxpayers, (3) the complexity of the tax law and administrative procedures, and (4) its information technology capacity. In general, the staffing strategy does not require a large number of staff in comparison to total staffing, but it does require a critical mass of highly trained ones. Many tax administrations delay considerably the staffing of their LTOs/NR units or keep them permanently understaffed; the NR compliance strategy cannot be effectively implemented in such circumstances.

\section{Salaries}

- Salaries must be adequate to attract and retain staff of the caliber needed for effective taxpayer administration and to discourage corruption. The problem of inadequate LTO remuneration may be aggravated in NR-rich countries. The salaries of NR specialists should, as much as possible, reflect private sector salaries and private sector differentials.

- Better wages and employment terms, along with stronger recruitment practices, should eventually strengthen capacity, although this will take time and depend on good performance management and promotion policies.

- A question that often arises on the recruitment of NR revenue administration is whether NR industrial specialists such as engineers, geologists, and mineralogists are required; the answer depends on the nature of the NR fiscal regime. It is advantageous, but not always possible, to recruit staff that combines accounting and taxation skills with NR industrial skills. NR specialists without tax and accounting skills will normally be required only for limited support roles.

\section{Recruitment Process and Job Description}

- The recruitment process needs to be transparent, based entirely on merit and free from any political influence. A mix of internal and external candidates may be useful. Internal 
staff already know the institution, tax laws, procedures and information technology systems, and can be easily trained. External staff with industry experience may be appropriate as they can provide industry knowledge to internal staff.

- A clear job description is needed to provide specific information on the position and the required skills and competencies. This clarifies the parameters on which candidates are evaluated and hired and thus makes the hiring process open and transparent.

- A tax administration needs to build capacity to monitor an industry whose mines, wells and exploration activities can continue for decades. Accordingly, the idea of outsourcing to resolve capacity issues, which exists in many developing countries, needs to be seriously analyzed from a longer term perspective. Conflict of interest may be present when external auditors belong to the same groups that are also involved in tax planning. When countries do opt for outsourcing, the private sector involvement should be used to build its administrative capacity through transfer of knowledge and skills, and never solely as a delegation of responsibility. Auditing taxpayers and assessing their correct tax obligation is a core function of government.

\section{Training}

- NR revenue administration staff need to be adequately trained. Although most of the training and skills needed for NR revenue administration are the same as those for general tax administration, specialist NR tax expertise should also be developed. Specialist training should cover a broad range of NR topics such as: (1) industry operations, in general and with particular reference to the specific country; (2) industry accounting; (3) tax legislation and the special issues it presents; (4) benchmark-based pricing; (5) volume and quality measurement, if the department concerned is responsible for these areas; and (6) multinational tax planning techniques, for example, transfer pricing, financing, and treaty shopping.

- Staff working on NR should also be trained in "soft skills," such as negotiation techniques and relationship building.

- Conflicts of interest may arise if NR companies are required to facilitate training for tax administration staff. This practice seems very common in many countries, but tax administrations should exercise caution to ensure that the difference between private and public sector interests are addressed.

- Exposure of policymakers and technical staff to the experiences of other countries in NR tax administration is a useful way to gain knowledge.

- Technical assistance from international organizations, such as the IMF, is also a useful way to enhance knowledge and skills levels on NR issues.

\section{Information Technology}

- NR revenue administrations need adequate and appropriate information technology, including hardware and software. The requirements for NR revenue administration are broadly similar to those for general tax administration, but there is a number of 
considerations, such as special NR taxes and procedures, which make NR taxation difficult to fit into standard systems. For instance, off-the-shelf information technology systems, common in developing countries, may not be appropriate for specific NR tax control.

- The exchange of information among government agencies is particularly vital, so systems need to be sufficiently compatible to support the regular exchange of data. Fragmented administration may make development of effective information systems particularly challenging.

\section{Budget and Autonomy}

- Tax administrations require adequate funding and reasonable autonomy over their operations, subject to proper audit and oversight. In particular, they need to be able to design their own internal structure, set staffing levels, set remuneration at levels necessary for recruitment and retention, hire and fire staff, and exercise discretion over capital as well as current expenditure.

- Funding by retention of a proportion of revenues collected is particularly inappropriate in the case of NR revenues. The size and the volatility of the revenue from natural resources make it an inappropriate measure for the amount of a suitable budget allocation for a tax administration, not allowing for a stable annual budgeting process.

\section{How Can Transparency Be Improved in NR Revenue Administration?}

Weak governance is considered to be the main explanation for the "resource curse." To maximize social and economic benefits, strong governance and capacity are essential along the whole value chain that turns NR endowments into sustainable development and poverty reduction. Transparency is a vital prerequisite for strengthening governance.

Corruption is one of the key concerns when dealing with a sudden and large amount of revenue inflow in tax administrations with low capacity. No simple measures exist to address this issue, and tax administrations should put in place a robust framework to combat corruption. Even though this framework should be in place for general tax administration, it is even more vital when dealing with NR, which present disproportionate risks for integrity breaches in low-income countries. A range of measures that minimize the opportunities for corruption and address occurrences as they arise include:

- One of the most important aspects of ensuring integrity is effective leadership and management of the tax administration. A dedicated and professional group of leaders and managers throughout the tax administration is vital to define the organization's culture and the boundaries of what is acceptable and unacceptable behavior by the tax administration's staff. 
- Establishing clear and transparent processes and procedures is key to preventing corruption. Documented procedures limit the degree of discretion that can be utilized and allows for a straightforward evaluation as to whether procedures are being properly followed.

- The organization should be properly designed, separating Headquarters' functions, such as planning and monitoring, from operational ones. Many tax administrations fragment power across multiple functions creating an organizational structure where no one is clearly responsible for a specific function. The clearer and less fragmented the assignment of responsibilities are, the more accountable the various parts of the organization will be.

- The adoption of stable, integrated, and reliable information technology systems is also relevant, as processes administered through the systems leave a trail to be followed, if adequately designed with logs and passwords.

- Payment should be made through banks and automated systems to avoid dealing with cash in tax offices. The latter is still common in many developing countries.

- A robust human resources policy, comprising open and transparent recruiting, adequate staffing and wage levels, systematic performance appraisal, good training, and career perspectives, is of utmost importance.

- A strong internal affairs function in the tax administration, properly staffed and with adequate powers, should be established. This function needs to enjoy independence to investigate and sanction corruption, including dismissing officials found to be engaging in or enabling corrupt practices.

- Appropriate division of duties and responsibilities limiting the opportunity to commit fraud need to be established. An internal audit function to independently test and evaluate control systems and specific operations is also required.

- Finally, it is important for tax administrations to have a Code of Ethics, which should be widely circulated inside and outside of the administration. Human Resources would normally create a discipline code that would spell out disciplinary outcomes for a breach of the Code of Ethics.

Naturally, combating corruption and enhancing transparency go beyond the tax administration itself; these should be concerns shared across governmental agencies. The IMF's Guide on Resource Revenue Transparency (GRRT) ${ }^{10}$ is a benchmark tool used for assessing transparency in the wider context of the whole value chain. The GRRT includes the combination of several criteria to achieve a holistic view of transparency. Table 3 summarizes the key requirements and aspects that the Guide covers and that are relevant to revenue administration.

\footnotetext{
${ }^{10}$ https://www.imf.org/external/np/fad/trans/guide.htm
} 
Finally, another important initiative to enhance transparency in the NR sector is the EITI. ${ }^{11}$ This initiative, launched in 2003, is a global coalition of governments, companies, and civil society entities to improve the openness and accountable management of NR revenues. EITI operates through a standard (last updated in July 2013), which contains a set of requirements that the international EITI board oversees. Countries voluntarily implement the standard to ensure that oil, gas, and mining companies fully disclose taxes and other payments to governments through EITI reports. It also provides a range of technical assistance to participant countries to comply with EITI objectives.

\footnotetext{
11 www.eiti.org
}

\section{TABLE 3. ENHANCING TRANSPARENCY: KEY REQUIREMENTS UNDER THE GRRT}

\begin{tabular}{|c|c|}
\hline $\begin{array}{l}\text { Clarity of Roles and } \\
\text { Responsibilities }\end{array}$ & $\begin{array}{l}\text { - Clearly established legal framework for government ownership of NR and the granting } \\
\text { of rights for NR development } \\
\text { - Clear and comprehensive publication of the government's policy framework and legal } \\
\text { basis for NR taxation or production sharing } \\
\text { - Clear specification of fiscal authority over NR-related revenue and borrowing; and full } \\
\text { disclosure of all NR-related revenue, loans, and assets } \\
\text { - Full disclosure of equity participation and explanation of its implications } \\
\text { - Clear definition of the ownership structure of NRCs and their fiscal role vis-à-vis the NR } \\
\text { ministry and finance ministry; and clear distinction of commercial from policy, regulatory, } \\
\text { and social responsibilities } \\
\text { - Clear definition of arrangements for NRCs or NR companies to undertake social or envi- } \\
\text { ronmental expenditure or provide subsidies to producers or consumers } \\
\text { - Well-defined arrangements to assign or share NR revenues between central and subna- } \\
\text { tional levels of government, which explicitly reflect national fiscal policy and macroeco- } \\
\text { nomic objectives }\end{array}$ \\
\hline Open Budget Process & $\begin{array}{l}\text { - Even though this aspect is mainly budgetary, not dealing directly with revenue administra- } \\
\text { tion issues, an important requirement is clear identification of all government NR revenues } \\
\text { through the government accounting system; and issuance of timely, comprehensive, and } \\
\text { regular reports to the public }\end{array}$ \\
\hline $\begin{array}{l}\text { Public Availability of } \\
\text { Information }\end{array}$ & $\begin{array}{l}\text { - Clear identification, description, and reporting of all NR revenue-related transactions, } \\
\text { including through resource funds, in the budget process and final accounts documents } \\
\text { - Publication of reports on government receipts of NR revenues as part of the government } \\
\text { budget and accounting process }\end{array}$ \\
\hline Assurances of Integrity & $\begin{array}{l}\text { - Internal control and audit procedures for handling resource revenue receipts through } \\
\text { government accounts or special fund arrangements, and public disclosure of spending of } \\
\text { such receipts through special funds } \\
\text { - Openness in the conduct of tax administration, so that NR companies understand their } \\
\text { obligations, entitlements, and rights; clear definition of the scope for discretionary action } \\
\text { by tax officials; and openness in the adequacy of sector skills and procedures } \\
\text { - Oversight of international companies and NRCs, including a requirement to comply with } \\
\text { internationally accepted standards for accounting, auditing, and accounts publication } \\
\text { - Oversight and reporting by a national audit office or other independent organization on } \\
\text { revenue flows between international companies/NRCs and the government and on any } \\
\text { data discrepancies. }\end{array}$ \\
\hline
\end{tabular}




\section{References}

Harrison, G. and R. Krelove, 2005, "VAT Refunds: A Review of Country Experience," IMF WP 05/218, International Monetary Fund.

International Monetary Fund (IMF), 2007, "Guide on Resource Revenue Transparency," http:// www.imf.org/external/np/pp/2007/eng/051507g.pdf

International Monetary Fund (IMF), 2012, "Fiscal Regimes for Extractive Industries: Design and Implementation," Washington. www.imf.org/external/np/pp/eng/2012/081512.pdf

International Monetary Fund (IMF) and World Bank, 2014 (forthcoming), Natural Resource Revenue Administration Handbook (International Monetary Fund and World Bank, Washington).

Kidd, M, 2010, "Revenue Administration: Functionally Organized Tax Administration," Technical Notes and Manuals, Fiscal Affairs Department, International Monetary Fund. http://www.imf.org/external/pubs/ft/tnm/2010/tnm1010.pdf

Sunley, E. and T. Baunsgaard, 2001, "The Tax Treatment of the Mining Sector: An IMF Perspective," Background paper prepared for World Bank workshop on the taxation of the mining sector, April 4-5, 2001.

World Bank, 2011, Wealth of Nations database. http://data.worldbank.org/data-catalog/ wealth-of-nations.

\section{Acronyms and Abbreviations}

$\begin{array}{ll}\text { AL } & \text { Arm's length } \\ \text { CIT } & \text { Corporate income tax } \\ \text { EITI } & \text { Extractive Industries Transparency Initiative } \\ \text { GRRT } & \text { Guide to Resource Revenue Transparency } \\ \text { IMF } & \text { International Monetary Fund } \\ \text { JV } & \text { Joint venture } \\ \text { KCM } & \text { Key Client Manager } \\ \text { LTO } & \text { Large Taxpayer Office } \\ \text { NAL } & \text { Non-arm's length } \\ \text { NR } & \text { Natural resources } \\ \text { NRC } & \text { National resource company } \\ \text { MNR } & \text { Ministry of Natural Resources } \\ \text { PSA } & \text { Production sharing agreement } \\ \text { PSC } & \text { Production sharing contract } \\ \text { RRT } & \text { Resource rent tax } \\ \text { SA } & \text { Self-assessment } \\ \text { TP } & \text { Transfer Pricing } \\ \text { TPC } & \text { Tax procedure code } \\ \text { VAT } & \text { Value Added Tax } \\ \text { WHT } & \text { Withholding tax } \\ & \end{array}$


TNM/14/02

International Monetary Fund

Fiscal Affairs Department

700 19th Street NW

Washington, DC 20431

USA

Tel: 1-202-623-8554

Fax: 1-202-623-6073 